\title{
End of the Lines
}

\author{
John Tavares
}

End of the Lines traite essentiellement des relations humaines et des schismes qui se créent entre les êtres, hommes et femmes, résultats de leur déloyauté, de leurs infidélités, de leur complaisance, des occasions qui se présentent à eux, des jugements qu'ils portent, bons ou mauvais ou quelque part entre les deux, et des conséquences matérielles de ces processus, interactions et réactions humaines.

Bourne had gotten on the city transit bus towards the end of the line, at the stop located a few blocks from his modest bungalow in the suburbs.

Today was a Saturday morning, Bourne having made it into the city and home after a three week long western road trip across cities and towns of the prairies, a sales drive promoting and selling the latest product - a herbal aphrodisiac - from a health food supplement and vitamin company into which he had heavily invested his savings. The herbal aphrodisiac had first caught attention of Bourne, who had been suffering acute psychological distress because of his impotence and difficulty maintaining firm erections, after he read a newspaper item about the locally manufactured supplement.

On Friday night, Bourne had gone out to a nightclub with Belinda, and, after losing track of his longtime girlfriend that evening, he left, slightly puzzled. Usually, when he returned home to the city after a sales trip, Belinda spent the evening with him. The last he had seen of his girlfriend, though, was with Collard, his colleague, his fellow salesperson with the health food, herbal supplement, and vitamin company.

Since Belinda was not having breakfast or coffee with him that morning, he had decided that he would go downtown, while he still had time off, before the next sales expedition, to check in at some electronic stores for the cost of computer upgrades, a new stick of random access memory, perhaps a high performance sound card. As the bus continued to work its way along Flaxfield Avenue, though, picking up weekend shoppers and clerks on their way to work at the shopping mall, it passed Collard's place. Collard, who had also invested heavily in the company for which they both worked as sales representatives, was practically converting and rebuilding his rambling house on Flaxfield Avenue into a mansion, installing solariums, Jacuzzis, saunas, and decks, and Bourne would have been the first to admit that he was filled with some resentment and jealousy of this selftaught home improvement expert and renovator. The bus stopped at the stop a few houses down from Collard's residence, and then, to his partial amazement, when he glanced up from the computer manual that he was reading, who should board 
the bus but Belinda, looking simply resplendent in her trim denim, tight cotton shirt cut above the navel, dressed for the summer even though it was a chilly spring morning, looking simply beautiful - indeed, the way he had left the previous evening.

Last night was an awkward time for Bourne, who found that, as the evening passed, Belinda seemed less interested in him and was spending plenty of time drinking, chatting, and dancing with Collard. Now, although he kept his head down, and was wearing sunglasses on this extremely bright day, hoping that Belinda would not notice him, apparently she did. She sat on the seat beside him, her hair smelling freshly shampooed, her body scented with perfume and fragrances. When she wordlessly came and sat beside him, though, he moved away towards the back of the bus. She turned back and looked at him with that questioning, almost pleading look in her eyes. She moved to the back of the bus, and, Bourne failing so much as to acknowledge her presence, moved away again. He sat in the middle of the bus this time, towards the place where the rear doors were located. Again, she stood up, moved, and tucked herself in beside him and he took a different seat again. She positioned herself down again beside him and reached out to touch his hand, tears in her eyes.

"I don't want you sitting beside me," Bourne said, and this time he simply continued highlighting passages from his book on computer repairs, maintenance, and upgrades with a fine point felt pen.

"What is wrong with you?" Belinda asked.

Bourne kept reading the section on connecting scanners and digital cameras, and when she did not get off at the shopping mall as he expected, he impatiently sat down on a seat again beside the doors saying, "I know you spent the night at Collard's."

Thinking he could even smell Collard's cologne or aftershave on her, he continued reading. The tears merely grew larger in her eyes. He could see them reflected off his sunglasses as he got up and stood by the doors.

"Don't you have to go to work?" he asked, glancing at his watch, which would reach noon in a few minutes. When he reached his stop, outside the main city auditorium and convention centre, he said softly, "Goodbye, Belinda, goodbye. Goodbye. Goodbye. Goodbye," in his repetitive, obsessive-compulsive manner, before he stepped off the bus in front of the city hall and planetarium. But she hurried off the bus after him and chased after him. As he tried to decide on whether he would go to the coffee house for a quick breakfast or straight to the electronic stores, he realized that Belinda was on his tail and walked first in one direction and then the next. She pulled at his collar.

"You can't do this to me," she whispered fiercely.

He pulled himself away from her grip. "Don't you have to go to work?"

"We need to talk." Belinda continued walking after him past the museum. "You can't just do this to me."

He started walking faster, but she caught up to him and tried to hold him. From behind she stuck her index finger into his mouth, in that personal gesture that private language they had had, that invited him to suck her finger and kiss up her hand, her arms, and continue to work his way upwards, but instead he thought 
it all seemed so silly and ended up spitting out her finger, lightly biting it. She dug her nail deep, scratching a long red curving line across his freshly shaved cheek that bled profusely, leaving a scar to remind him every time he shaved.

"You can't do this to me," she sobbed.

"I can," he said, getting a tighter grip on the soft cover book under his arm as he walked away, losing himself in the crowd downtown, before adding, to nobody but himself, as if seeking reassurance, self-confidence, "and I will." 